\title{
Bacterial leaf spot of Guazuma ulmifolia (Lam.) caused by Xanthomonas axonopodis
}

\author{
Marli de Fátima Stradioto Papa ${ }^{1}$; Suzete Aparecida Lanza Destéfano ${ }^{2}$; Lucas Mateus Rivero Rodrigues ${ }^{3}$; Mariana \\ Ferreira $^{2}$; Júlio Rodrigues Neto ${ }^{2}$
}

${ }^{1}$ UNESP, Campus de Ilha Solteira, 15385-000, Ilha Solteira, SP. ${ }^{2}$ Lab. Bacteriologia Vegetal, Instituto Biológico, Cx. Postal 70, 13001-970, Campinas, SP. ${ }^{3}$ UNESP, Campus de Botucatu, Departamento de Produção Vegetal, 18603-970, Botucatu, SP.

Autor para corres pondência: Júlio Rodrigues Neto e-mail: julio@biologico.sp.gov.br

Data de chegada: 01/02/2007. Aceito para publicação em: 01/12/2008

\section{ABSTRACT}

Papa, M.F.S.; Destéfano, S.A.L.; Rodrigues, L.M.R.; Ferreira, M.; Rodrigues Neto, J.. Bacterial leaf spot of Guazuma ulmifolia (Lam.) caused by Xanthomonas axonopodis. Sum m a Phytopathologica, v.35, n.2, p. 146-147, 2009

During the years 2002 to 2006 symptoms of leaf spot, consisting of necrotic lesions on the mesophil and close to veins and leaf margins were observed on Guazuma ulmifolia trees in a field at Ilha Solteira county (State of São Paulo) and Selviria (State of Mato Grosso do Sul). Gram negative bacteria of yellow coloured colonies on YSG media were isolated from typical lesions and pathogenicity of strains were confirmed on artificialy inoculated leaf on healthy plants. The biochemical and physiological tests, xanthomonadin production and molecular tests using PCR-RFLP of the 16S-23S rDNA indicated that the isolates belong to the species Xanthomonas axonopodis.

Palavras-chave adicionais: Guazuma tree, phytopathogenic bacteria, 16S-23S rDNA

\section{RESUMO}

Papa, M.F.S.; Destéfano, S.A.L.; Rodrigues, L.M.R.; Ferreira, M.; Rodrigues Neto, J..Mancha bacteriana das folhas de Guazuma aulmifolia (Lam.) causada por Xanthomonas axonopodis. Sum ma Phytopathologica, v.35, n.2, p. 146-147, 2009

No período de 2002 a 2006, nas regiões de Ilha Solteira, Estado de São Paulo, e Selvíria, Estado de Mato Grosso do Sul, foram observados em árvores de Guazuma ulmifolia sintomas de machas necróticas e irregulares nas folhas, distribuídas no mesófilo ou próximo das nervuras. Das lesões, foram isoladas bactérias Gram negativas, com colônias de

Keywords: mutamba, bactéria fitopatogênica, 16S-23S DNAr coloração amarelada em meio YSG, e que inoculadas em plantas sadias reproduziram os sintomas observados no campo. Testes bioquímicos, fisiológicos, produção de xanthomonadina e testes moleculares de PCRRFLP da região espaçadora $16 \mathrm{~S}-23 \mathrm{~S}$ rDNA indicaram que os organismos isolados pertencem à espécie Xanthomonas axonopodis.
Guazuma ulmifolia Lam., family Sterculiaceae, common named as "mutamba" in Brazil, is a medium-sized tree widely distributed throughout the Caribbean, Mexico, Central and South America, recommended for restoring degraded areas. Mutamba wood has multiple purposes such as carpentry, light construction, boxes and crates, as well as firewood and charcoal. Its extracts have also been used as antiinflammatory, antioxidant and antiviric in popular medicine.

During the years 2002-2006, at the Campus of the State of São Paulo University (UNESP), Ilha Solteira, State of São Paulo, and Selviria County, State of Mato Grosso do Sul, diseased leaves of mutamba trees were o bserved. Symptoms consisted of reddish-brown, irregular lesions on the mesophil, near to main and secondary veins, and leaf margins. On the upper leaf surfaces the lesions appeared as reddish spots, and some enlarged lesions became surrounded by a chloroctic halo and V-shaped along the leaf margin (Figure 1). Frequently, the midrib major veins also showed enlarged but rarely water-soaked lesions. Symptoms on flowers, peduncles or fruits were not observed. Pathogenic fungi on G. ulmifolia were reported, like Helminthosporium milioloides, Meliola sp., and Dictyocephala ulmifolii, (4) but in this study no fungi structures were detected on the lesions.

From diseased leaves, a Gram-negative slow-growing bacterium was consistently is olated. Yellow brightening colonies with approximately $1 \mathrm{~mm}$ in diameter developed within 4-5 days at $28^{\circ} \mathrm{C}$ on Nutrient Agar (NA) medium, and the growing was faster on YSG (Yeast extract $0.5 \% ; \mathrm{NH}_{4} \mathrm{H}_{2} \mathrm{PO}_{4} 0.05 \% ; \mathrm{K}_{2} \mathrm{HPO}_{4} \quad 0.05 \%$; $\mathrm{MgSO}_{4} .7 \mathrm{H} 2 \mathrm{O} 0.02 \%$; gluc ose $0.5 \%$; agar $1.7 \%$; $1000 \mathrm{~mL}$ distilled water). Fifteen strains were obtained and according to the methodology described by Lelliott \& Stead (2), the following characteristics were observed: oxidative metabolis $m$ of glucose, oxidase, urease and nitrate reduction negative, catalase and $\mathrm{H}_{2} \mathrm{~S}$ from cysteine production were positive, and as paragine utilization negative. Aesculin and starch were hydrolyzed, but not gelatin. Acid was produced from the following carbohydrates: $\mathrm{D}(+)$ trehalose, D-xylose, maltose, glycerol, $\mathrm{D}(-)$ sorbitol, meso-ino sitol, but not from D(-) arabinose, adonitol, lactose, erythritol, inulin and salicin. Organic acids utilized were meso-tartarate, succinate, glutarate, malonate and DL-lactate, and not L-tartarate. Trigoneline was used, but not D-alanine and DL-homoserine. Also, the isolated strains produced the pigment xanthomonadin, according to Lelliott \& Stead methodology (2).

Pathogenicity tests were performed in a greenhouse with three selected bacterial strains (IBSBF 1796, IBSBF 2076 and IBSBF 2080). Artificial inoculations were made on leaves by puncturing with entomological needles and spraying with bacterial suspensions $\left(10^{7}\right.$ 


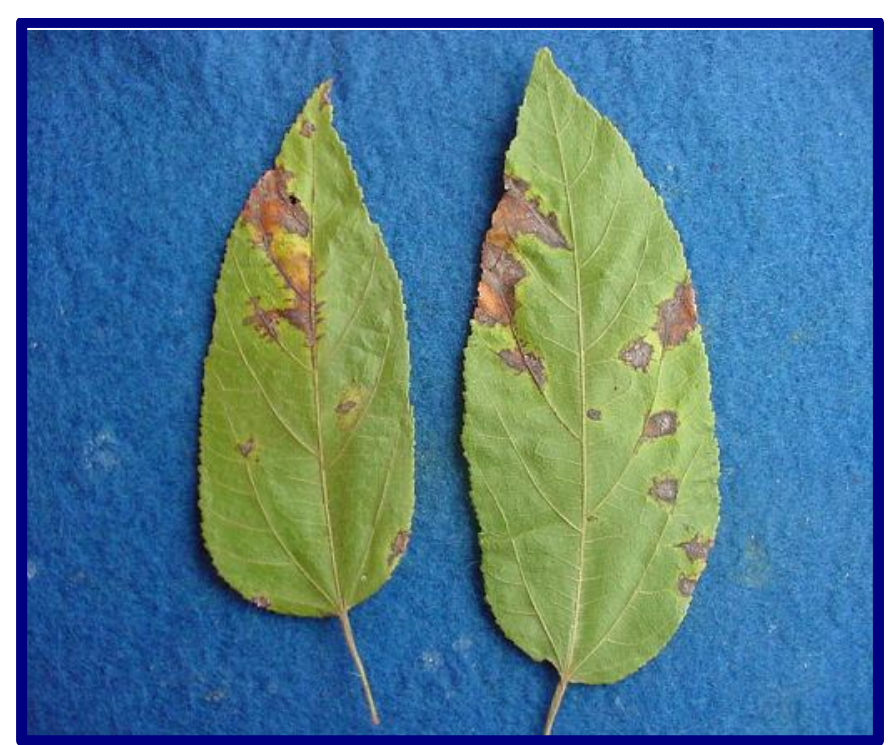

Figure 1. Natural symptoms of necrotic and irregular lesions on leaves of Guazuma ulmifolia caused by Xanthomonas axonopodis.

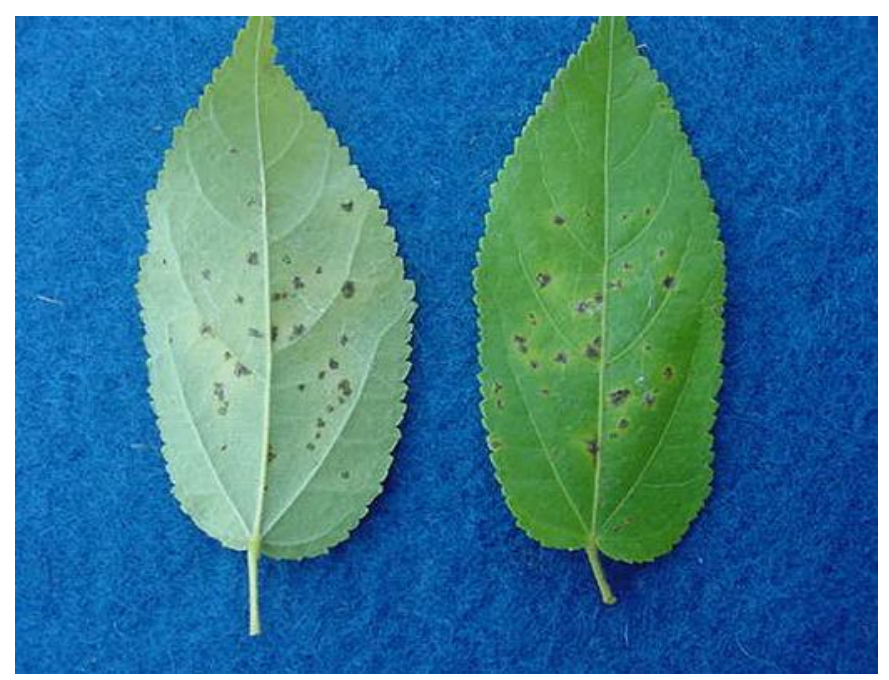

Figure 2. Artificial inoculation on Guazuma ulmifolia leaves with the strain IBSBF 2080 of Xanthomonas axonopodis, recorded after 21 days.

CFU.mL $L^{-1}$ ) prepared with sterile distilled water. Three pot-cultivated plants of G. ulmifolia were tested. In addition, the plant species of Bauhinia forficata, Citrus sinensis, Eucalyptus grandis, Fragaria hib., Glycine max, Coffea arabica cv. Catuai, Capsicum annuum, Mangifera indica, Lycopersicon esculentum, Passiflora edulis f. flavicarpa, Phaseolus vulgaris and Rubus idaeus were also tested for evaluating the plant species host range. Control plants were inoculated with sterile distilled water. The inoculated plants were enclosed in polyethylene bags for 3 days to mantain high humidity, and the symptoms were recorded up to 21 days. Only plants of $G$. ulmifolia showed symptoms of leaf spots (Figure 2), indicating the specificity to this host.

Molecular tests were carried out aiming to identify the mutamba isolates at species level using the PCR-RFLP of the 16S-23S rDNA spacer region. The type strains of Xanthomonas campestris pv. campestris (IBSBF $1163^{\mathrm{T}}$ ) and Xanthomonas axonopodis $\mathrm{pv}$. axonopodis (IBSBF 1444 ${ }^{\mathrm{T}}$ ) were used for comparison purposes. Genomic DNA was extracted as described by Pitcher et al. (5) and the PCR amplification of the 16S-23S rDNA spacer region was performed as described by Destéfano and Rodrigues Neto (1). The amplification yielded a unique band of approximately 1.1 kilobase $(\mathrm{kb})$ for all the strains tested. PCR products $(5 \mu \mathrm{L})$ were digested, individually, with each of the following res triction endonucleases $A f a$ I, Alu I, Dde I, Hae III, Hinf I, Hpa II and Mbo I under conditions specified by the manufacturer. The restriction fragments were separated by electrophoresis in 3\% agarose gels in $1 \mathrm{X}$ TAE buffer (3). The gels were stained with $0.1 \mu \mathrm{g} \cdot \mathrm{mL}^{-1}$ of $\mathrm{EtBr}$ and then photographed under ultraviolet transillumination using an Alpha Innotech 2200 digital system. In all experiments, the mutamba isolates showed identical profiles with $X$. a. pv. axonopodis, except for Mbo I digestions in which they presented distinct pattern bands when compared with the species $X . a$.pv. axonopodis and X. c. pv. campestris.

The biochemical and molecular tests performed confirmed the taxonomic position of the mutamba isolates as belonging to the $X$. axonopodis species. This is the first record of a bacterial disease on mutamba. The identific ation of bacteria at pathovar level is in progress.

\section{REFERENCES}

1. Destéfano, S.A.L.; Rodrigues Neto, J. Rapid differentiation of Xanthomonas strains causing disease in citrus plants by PCRRFLP of the 16S-23S rDNA spacer region. Summa Phytopathologica, Botucatu, v. 28, n.2, p.167-172, 2002.

2. Lelliott, R.A.; Stead, D.E. Methods for the diagnosis of bacterial diseases of plants. Oxford, UK: British Society of Plant Pathology; Blackell Scientific, 1987. 216p.

3. Maniatis, T.; Fritsch, E.F.; Sambrook, J. Molecular cloning: a laboratory manual. $6^{\text {th }}$, New York, Cold Spring Harbor, 1983. $545 \mathrm{p}$.

4. Mendes, M.A.S.; Silva, V.L.; Dianese, J.C.; Ferreira, M. A. S. V.; Santos, C.E.N.; Gomes Neto, Ed.; Urben, A.,F.; Castro, C. Fungos em Plantas no Brasil. Brasília: Embrapa-SPI, Embrapa-Cernargem, 1998. 569p,

5. Pitcher, D.G.; Saunders, N.A.; Owen, R.J. Rapid extraction of bacterial genomic DNA with guanidine thiocyanate. Letters in Applied Microbiology, Oxford, v. 8, p. 151-156, 1989. 